\title{
Research. \\ CONSUMER PURCHASING DECISIONS OF TEH PUCUK HARUM : PRODUCT QUALITY, ADVERTISING AND BRAND IMAGE
}

\author{
Surya Bintarti ${ }^{1)}$; Suwandy ${ }^{2}$ \\ Department of Management. Universitas Pelita Bangsa \\ surya.bintarti@pelitabangsa.ac.id ${ }^{1 *}$; swandy262@gmail.com²) \\ ${ }^{*}$ Corresponding author
}

Received: December 27, 2021 Accepted: December 30, 2021 Published: December 31, 2021

To cite this article: Bintarti, S; Suwandy, S.; (2021). Consumer Purchasing Decisions of Teh Pucuk Harum : Product Quality, Advertising and Brand Image. The Management Journal Of Binaniaga, 6 (2), 229- 244 . doi: 10.33062/mjb.v6i2.480

\begin{abstract}
Tea that can be enjoyed quickly, perfect for a bundle, is a drink that many people like, as is Teh Harum Pucuk. This drink is one of the ready-to-drink tea drinks that are packed with great experience from previous years, so that they can compete with other packaged ready-to-drink tea drinks. Fans of ready-to-drink tea packages come from various circles, including students, workers, the general public, and college students. This review plans to examine the impact of the quality of goods, publications and brands in general on the Purchasing Decision of fragrant shoots tea products. The testing technique used is non-likelihood inspecting, specifically the purposive testing strategy. The examples in this review are 75 individuals, especially individuals who have purchased ready-to-drink tea drinks that are bundled with the brand of Teh Pucuk Wangi and information is collected by distributing Google from polls, the information collected is tested for validity with legitimacy and steadfast quality tests, information investigation procedures using the PLS program. The results of a helpless exploration show that the quality of goods and publicity factors in ready-to-drink foods bundled with teh pucuk wangi has a positive effect on purchasing choices, and brand image has a negative effect on purchasing choices of pucuk harum.
\end{abstract}

Keywords ; Purchasing Decision, Product Qualitu, Advertising, Brand Image

\section{INTRODUCTION}

Trends in public consumption patterns in the packaged ready-to-drink tea sector and the efforts of entrepreneurs to sell ready-to-drink tea products have made the product continue to show sales growth. One of the administrators who is in an association of bottled beverage entrepreneurs said that drinking packaged ready-toserve tea is the sector with the best performance and consistently growing. Changes in people's lifestyles, tea has become the most preferred beverage product by the Indonesian people. According to the data from Nielsen Indonesia throughout January to August 2019 it reached Rp. 12.37 trillion, this achievement grew from 2018 which recorded sales of Rp. 11.96 trillion and $2017 \mathrm{Rp} .11 .81$ trillion.

The growth of consumption of ready-to-drink tea drinks in Indonesia ranks high after mineral water. According to reliable sources, in 2014, the number of people consuming ready-to-drink tea in Indonesia reached 2,000,000,000 liters or 1.07 pounds $(0.5 \mathrm{~kg})$ of tea leaves per person in a year. From these data, packaged readyto-drink tea is listed as the most popular type of tea in Indonesia and is the second largest after brewed tea (Dina Agustina, 2015).

Sinar Sosro in 1974, which has long been popular with the Indonesian people, has now lost its market share. The high level of competition in the beverage industry,

Surya Bintarti; Suwandy. Consumer Purchasing Decisions of Teh Pucuk Harum : Product Quality, Advertising and Brand Image 
especially packaged ready-to-serve tea drinks, which are increasingly diverse will affect the level of consumer purchasing decisions. flavor variants and brands of packaged ready-to-drink drinks continue to compete according to their respective markets and consumers will be faced with various types of drinks with different variations. The public's need for packaged ready-to-drink tea products has attracted the attention of young companies such as PT. Mayora Indah Tbk which launched The Pucuk Harum products in 2011, PT. Coca-Cola on Frestea products in 2002, PT. Orang Tua Group on Glass Tea products in 2007, PT. Ichi Tan Indonesia on Ichitan products in 2014, PT. Garuda Food Tbk on Mountea products in 2005, PT. Ultra Milk Industries in 1979 The Kotak products, PT. Indofood CBP Sukses Makmur Tbk on Ichi Ocha products, in 2014, PT. ABC President Indonesia at Nu Green Tea 2005 (Rheisiki, 2016).

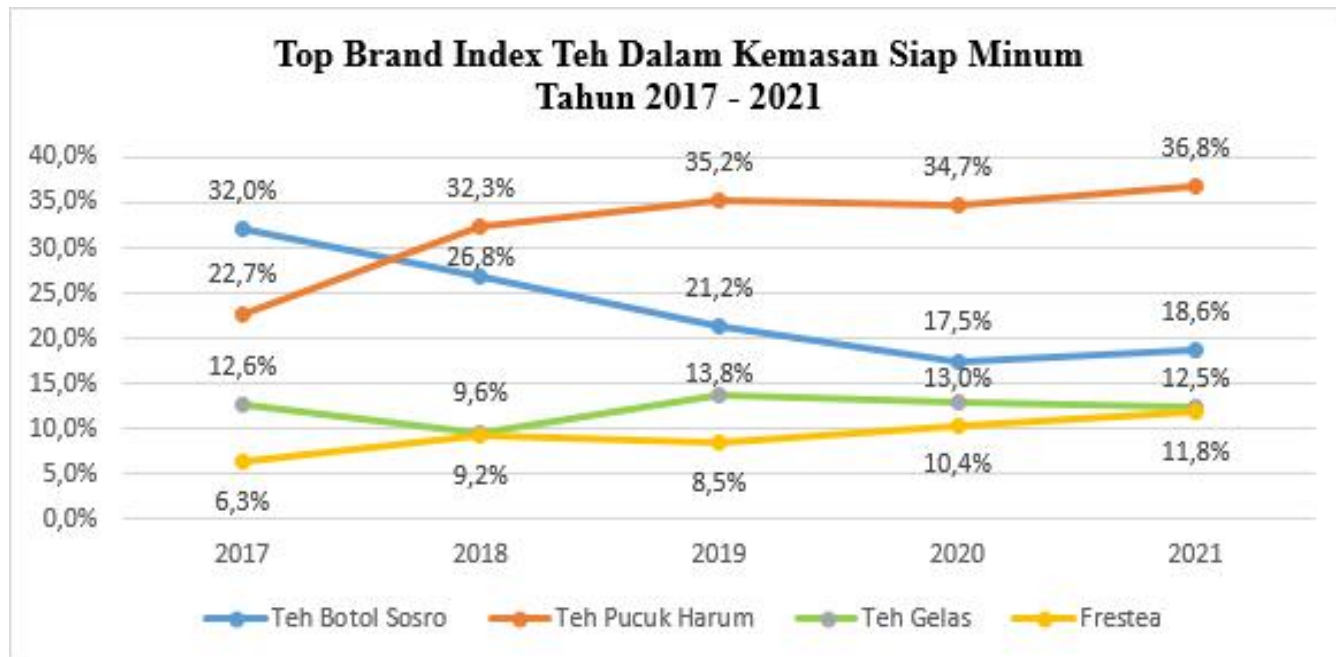

Figure 1 Percentage of Sales of Ready-to-Drink Tea Drinks that are packaged Ready to Drink

Source: Top Brand Index 2017-2021

According to the data in Figure 1 shows ready-to-drink tea that is packaged ready to drink, the Teh Pucuk Harum brand being the most favorite packaged readyto-serve tea occupies first place for four consecutive years, namely in 2018-2021 with a top brand index of $32.3 \%, 35.2 \%, 34.7 \%$ and in $202136.8 \%$. Meanwhile, Teh Botol Sosro experienced a decline every year as there was competitors who continued to innovate and create new products. This decline occurred within 4 years. in 2021 Teh Botol Sosro was in the 2nd position of the top brand index with $18.6 \%$, while Teh Gelas was only $12.5 \% \quad$ and Frestea $11.8 \%$.

Expanding the share of the industry as a whole and competition for packaged ready-to-drink tea drinks to get buyer's premium and consideration of advertised products are the main considerations to be able to face competition in displaying products. The promotional system carried out by PT Mayora Indah Tbk to customers of Teh Pucuk Harum products uses natural ingredients that are really selected from the tips of selected tea leaves and procedures for presenting Teh Pucuk Harum products through correspondence as advertisements on TV media and brand placement in the buyer's personality.

Present customers are more selective in choosing the goods to be used because of the many goods offered and enjoy various benefits from each other. The purchase option turns into a decision of at least two elective decisions (Tjiptono, 2015, p.387). Purchasing choice is the perspective that buyers go directly from recognizing needs, making decisions, and selecting certain items and brands, in this way filling in as a decision progression before committing to the buying activity itself. Buyer's Purchasing Decision cannot be distinguished from the impact of several elements including advertising factors that combine items, bundling style, progress, distribution, 
administration and value (Mutsikiwa and Marumbwa, 2013) according to Kotler and Keller (2009: 235). The Purchasing Decision interaction consists of five phases, namely recognition of the specific problem, data search, option assessment, Purchasing Decision, and post-purchase behavior. Sources of data can be obtained from various sources, one of which is business sources such as promoting by utilizing TV media.

Item quality reflects the item's capacity to complete its obligations which combines toughness, dependability or progress, strength, simplicity of bundling and item repair (Kotler and Armstrong, 2008:266). The quality of goods implies that buyers will be satisfied if the results of their assessment show that the goods they use are the best (Lupioadi, 2001:158). Viewed item quality can be characterized as the way the client perceives the item's image value and is generally superior to other accessible options (Aaker, 1991; de Chernatony, 2009). This identifies with the client's mentality towards general brand insights rather than attributes of explicit items alone (Zeithaml, 1998). Agarwal and Tea (2004). Client assessments will use item execution, such as the degree to which items conform to assembly guidelines and item explicit properties, to survey item quality, whereas in Xiapon Wang's (2018) test article describing the positive effect of enthusiastic audit substance on item quality clearly.

Publication is a type of message that is forwarded to a wider local area using the media. The term publication refers to an understanding of the overall interaction which includes the readiness, arrangement, implementation, and supervision of message delivery (Niken, 2007: 127). Publishing is a type of correspondence that relies on data about the advantages of an item, which is masterminded so that it creates feelings of pleasure that will adjust the individual's perspective to make a purchase (Tjiptono, 2008:226). If an announcement has a strong allure, it will open up the possibility that promotional data will be seen (Indiarto, 2006). Promotion can be used adequately to compile a picture of the product and organization that is attracted and can also trigger purchases (Tjiptono, 2008: 52), while in a research article by Mohammed Z Salem (2018) that buyers' views about double-dealing in publications are contradictory to influence purchases. choice, research. This is supported by the assessment of Sheep et.al. (2001: 192) explains that four factors from a combination of limited time can influence buyers in making Purchasing Decisions, one of which is publication. The brand picture is a depiction of the buyer's trust relationship with a particular brand. (Tjiptono, 2008) brand image is a general view of an item, seen from understanding the data of an item (He, Sha, and Yang, 2013). Brand image also helps buyers understand their needs and desires for a particular brand and to separate one item from another (Anwar and Gulzar, 2011). The better the brand image, the more confident the customer's attitude towards the product (Aghekyan-Simonian, Forsythe, Suk Kwon, and Chattaraman, 2012). In addition to influencing Purchasing Decisions, brand image also affects clients' self-esteem (Hasby Irwanto and Husein, 2018). A brand that is considered certain can give buyers pride in using these goods. This pride is an added value that can be obtained by buyers, while in the exploration of Siti Nurhayati, (2017), it is explained that brand image has no impact on Purchasing Decisions. In addition, the brand image does not become an additional reference for potential buyers and becomes a thought for the ideal product. Brands that are generally known to the general public and can be said to have a good brand image, so that individuals today do not consider it in choosing to buy. For customers, a good brand image may not actually make them need to buy or try the item. Some buyers think about different things, for example, the nature of the goods determined by friends or according to their own wishes. Purchasing decision is a dynamic cycle of buyers to buy cash, combining information to select at least two accessible option items, influenced by several components, including quality, value, area, progress, convenience, administration and others. Buying options are customer activities to buy or not to the goods. Of the various components that influence customers in buying an item or administration, usually buyers consistently think of quality, price and items that stand out to people in general. (Lupiyoadi, 2008). Express purchase options and postpurchase behavior. Buying option is an idea in buying behavior in which the customer 
chooses to act or get something done and for this situation make a purchase or take advantage of a particular item or administration. (Tan Teok Ming et al., 2012). Saying if an item already had its own qualities, he would really want to work with the opponent of the item. Based on the above basis, the exploratory question is whether the quality of goods, publication exercises and brand image of Teh Pucuk Harum will affect the Purchasing Decision of ready-to-drink tea drinks bundled with Teh Pucuk Harum?

\section{Purchasing Decision}

\section{LITERATURE REVIEW}

Purchasing decision is the practice shown by the customer in finding, giving, valuing and disposing of an item and administration that is relied upon to meet his or her needs. Schiffman and Kanuk (2007). Meanwhile, according to Tjiptono (2008). Choice buying is a cycle in which the customer understands the problem, finds out the facts about a particular item or sign and assesses how well each option solves the problem, which then, at that point, drives the Purchasing Decision. (Kotler in Sumardjono \& Ardila, 2018) Buying choice is a measure of critical thinking which consists of dissecting or understanding needs and wants, searching for data, assessing sources of elective buying choices, buying choices, and behavior after buying. Buyers' purchasing choices are gradually being used by buyers to buy labor and products (Sheep, 2008: 23). As per Kotler and Keller (2012) clarified that the buyer goes through five phases during the time spent purchasing an item including Problem Recognition, Data Search, Choice Assessment, Purchasing Decision, Post Purchase.

\section{Product Quality}

The quality of goods reflects the capacity of goods to complete their obligations which combines robustness, dependability or progress, strength, simplicity of bundling and repair of goods (Kotler and Armstrong, 2008:266). The quality of goods implies that buyers will be satisfied if the results of their assessment show that the goods they use are the best (Lupioadi, 2001:158). Quality of goods is the capacity to provide the best to meet what is needed and needed by an item or administration by relying on the supplier of goods or administration on the premise of the client (Joseph P. Gun et., al: 2008). Meanwhile, as shown by (Fandy Tjiptono, 2006) the quality of goods is a condition related to goods, administration, which goes beyond assumptions.

\section{Advertising Theory}

Publishing is one of the four essential things companies use to deliver attractive exchanges to designated buyers and networks. Basically, publication is a kind of correspondence to fulfill display capacity. Tjiptono (2008). explained that publication is one of the most common types of promotion used by organizations in promoting their products. Likewise, according to Machfoedz (2010). that publication is any kind of distorted data and promotion by customers to present suggestions, personnel and products. Meanwhile, as pointed out by (Kotler and Keller, 2010:132). Publication is any kind of non-individual display and development of thoughts, work and products by a particular proponent for a fee.

\section{Brand Image}

Brand image can be characterized as an affirmation that appears in the customer's personality when remembering the brand of a particular item. Tjiptono (2008), implied by brand image is a description of affiliation and buyer beliefs about a particular brand. As Kotler and Keller (2009) point out, brand image is a cycle in which an individual selects, aggregates, and elaborates data contributions to create a significant image. Kertajaya (2007), explains his perspective that what is implied by the brand image is the energy of all identified affiliations with the brand that has hitherto existed in the customer's personality. 
According to the discussion and the existence of research on this matter, I tried to formulate the problem that has been determined to be answered with the following hypothesis:

- Assumed that product quality will have an influence on purchasing decisions for The Pucuk Harum;

- Assumed that advertising will have an influence on purchasing decisions The Pucuk Harum;

- Assumed that brand image will have an influence on purchasing decisions for The Pucuk Harum.

\section{RESEARCH METHOD}

\section{Research Design}

This scientific work examines ready-to-drink tea drinks packaged with The Pucuk Harum products produced by PT Mayora Indah Tbk, which is a popular tea beverage product in Indonesia. Even though it is a newcomer brand, Teh Pucuk Harum which was launched in the market in 2011 has been successful in the market. Teh Pucuk Harum is able to surpass several previously circulating brands such as Ultra's Teh Kotak, Teh Gelas and Frestea. The achievements of Teh Pucuk Harum in the last four years, namely 2018, 2019, 2020 and 2021 were able to rank I Top Brand Index (TBI) and were able to become the market leader replacing Teh Botol Sosro.

This review attempts to measure the extent to which these social wonders are impartial, so it can be said that this kind of exploration uses a strategy known as quantitative methodology. According to Sugiyono (2017), affiliated examination is an exploration that asks for the relationship between at least two factors and a quantitative methodology (Sugiyono, 2016: 7). is a type of information that can be estimated directly, as data or clarification communicated in numbers or as a number, with this test it will be feasible to build hypotheses that can explain, anticipate and control the relationship or impact of autonomous factors. Quality of goods (X1), Publish (X2) Brand description (X3) on the dependent variable Buyer's Purchasing Decision.

The population in this review are buyers who have purchased and burned fragrant shoots tea. The population in this review is very large and unlimited, so the testing in this review uses a non-probability testing strategy with the incidental testing method. Accidental testing is an inspection procedure that depends on the possibility, that is, a buyer who accidentally/unexpectedly meets an analyst can be used as a test, in the event that it is considered that the individual met is worthy as a source of information, Sugiyono (2017).

The number of residents is not limited and the exact number of buyers of Teh Pucuk Harum is not known, so to determine the size of the sample in this review, it depends on Roscoe's view in Sugiyono (2011: 90). i.e the number of tests that fit in the review is between 30 to 500 respondents. Based on this hypothesis, the number of tests in this review adds up to 75 respondents who are buyers of Teh Pucuk Harum.

\section{RESULT AND DISCUSSION}

According to the results of the descriptive analysis, it shows that the results of the responses from respondents to the Purchasing Decision variable $(\mathrm{Y})$. Most of them stated Agree with the mean value of all indicators of 4.153 (Interval value $3.41-4.20=$ Agree). The highest mean value is found in the indicator of 4.280 , namely the statement "Consumers make purchasing decisions on ready-to-drink tea drinks packaged with the Teh Pucuk Harum brand because the products are of good quality". Based on the results obtained, it shows that Pucuk Harum Tea products are of good quality and of good quality so that they are able to make consumers make purchasing decisions for Teh Pucuk Harum products and even want to recommend them to those closest to them.

Discriminatory validity of the reflexive indicator can be seen from the correlation

Surya Bintarti; Suwandy. Consumer Purchasing Decisions of Teh Pucuk Harum : Product Quality, Advertising and Brand Image 
between constructs or seen from the cross loading on the PLS Algorithm. The following is the result of cross loading from SmartPLS processing that the correlation of the Brand Image construct (X3) with its indicators is higher than the correlation of the KTP and IK indicators with other constructs $(Y$ and $X 1)(Y$ and $X 2)$. Smart pointers can be found in the cross stack between the marker and the building. A pointer is valid if it has the highest stacking factor for the expected build compared to the stacking factor for various builds. Therefore, inactive agreements anticipate markers in their boxes better than pointers in different boxes (Ghozali, 2014).

Next is discriminant validity which can also be obtained in other ways, namely by looking at the average variant extracted (AVE) value for each indicator, it is required that the value must be $>0.5$ for a good model (Ghozali, 2014).

Table 1

Average Variance Extracted

\begin{tabular}{|l|l|}
\hline & \\
& \\
\hline Brand Image (X3) & 0.710 \\
\hline Advertising (X2) & 0.641 \\
\hline Product Quality (X3) & 0.615 \\
\hline Purchashing Decision (Y) & 0.649 \\
\hline
\end{tabular}

Source: Primary Data Processing Results, 2021

From table 1 it can be seen that assessing construct validity by looking at the AVE value, a good model is required where the AVE in each construct is greater than 0.5 (Chin, 2010 in Imam Ghozali and Hengky Latan, 2020). It can be seen in table 4.6, the AVE output results show that having an AVE value greater than 0.50 means that all constructs in the study have good discriminatory validity.

Realibilty Test

In the following estimation test, an unshakable quality test is carried out. An immovable quality test is carried out to show the accuracy, consistency, and fairness of the instrument in estimating a building. In PLS Sem, utilizing SmartPLS to measure immovable build quality should be possible in two ways, specifically with alpha dependency and Cronbach Composites. the use of cronbach's alpha to test a development will give a lower price (under gauge) so it is more advisable to use a solid composite quality.

Table 2 Construct Reliability dan Validity

\begin{tabular}{|l|c|c|c|}
\hline & Cronbach'Alpha & rho'A & $\begin{array}{c}\text { Composite } \\
\text { Realiability }\end{array}$ \\
\hline Brand Image (X3) & 0.917 & 0.924 & 0.936 \\
\hline Advertising (X2) & 0.937 & 0.941 & 0.947 \\
\hline Product Quality (X1) & 0.951 & 0.954 & 0.957 \\
\hline Purchasing Decision (Y) & 0.922 & 0.924 & 0.937 \\
\hline
\end{tabular}

Source: Primary Data Processing Results, 2021

From Table 2 it can be seen that all variable values in reliability testing use either Cronbach's alpha or Composite reliability. The value is $>0.7$. Therefore, it can be concluded that the variables tested are valid, so that it can be continued for structural model testing.

Surya Bintarti; Suwandy. Consumer Purchasing Decisions of Teh Pucuk Harum : Product Quality, Advertising and Brand Image 


\section{Data Analysis Test}

This research uses a structural equation modeling (SEM) model, and software that uses SmartPLS 3,3,3. The results of the analysis of the study are as follows:

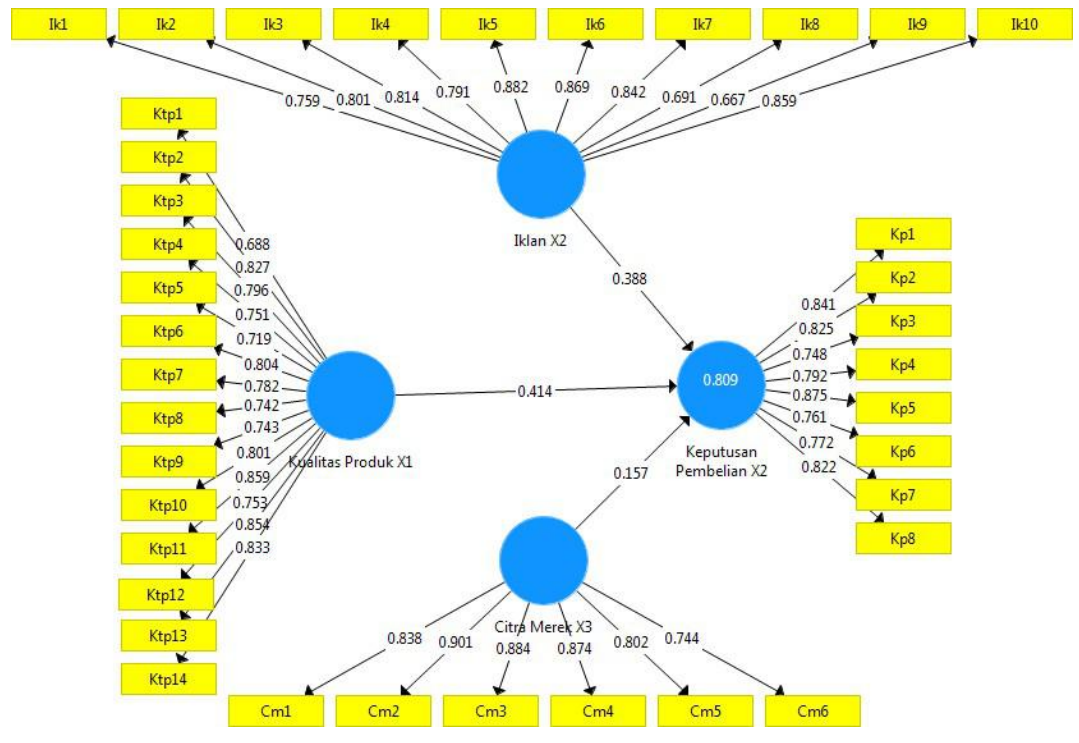

Figure 2 Path Diagram

Source: Primary Data Processing Results, 2021

The output results of the PLS algorithm analysis with the measurement model in Figure 2 can be translated as follows:

1. Product Quality Variable $\left(\mathrm{X}_{1}\right)$

a. Product Quality Variable (X1) as measured through the instrument. The appearance of the packaging design for Teh Pucuk Harum products looks good and attracts attention (KTP11) which occupies the highest role in influencing the purchasing decision variable $(\mathrm{Y})$ which is 0.859 .

b. Product Quality Variable (X1) as measured through the instrument of Teh Pucuk Harum products made from natural ingredients that are free of artificial dyes and sweeteners (KTP13) is 0.854 .

c. Product Quality Variable (X1) which is measured through the instrument of Teh Pucuk Harum products has a good brand image reputation in consumers (KTP14) which is 0.833.

d. Product Quality Variable (X1) which was measured through the Teh Pucuk Harum product instrument was a refreshing tea drink (KTP2), which was 0.827.

e. Product Quality Variable (X1) which is measured through the Teh Pucuk Harum product instrument always maintains consumer confidence (KTP6), which is 0.804 .

f. Product Quality Variable (X1) which was measured through the instrument of expiry period of Teh Pucuk Harum products was right according to the standard (KTP10) which was 0.801.

g. Product Quality Variable (X1) as measured through the Teh Pucuk Harum product instrument has an attractive packaging design (KTP3) which is 0.796 .

h. Product Quality Variable (X1) which was measured through the Teh Pucuk Harum product instrument in accordance with the laboratory test (KTP7) which was 0.782 .

i. The Product Quality Variable (X1) as measured by the Teh Pucuk Harum

Surya Bintarti; Suwandy. Consumer Purchasing Decisions of Teh Pucuk Harum : Product Quality,

Advertising and Brand Image 
packaging design instrument was more varied in terms of color, shape and size (KTP12), which was 0.753 .

j. Product Quality Variable (X1) which was measured through the Teh Pucuk Harum instrument had a distinctive packaging design characteristic (KTP4), which was 0.751

k. Product Quality Variable (X1) which is measured through consumer instruments chooses Teh Pucuk Harum products because of its good durability (KTP9) which is 0.743

1. Product Quality Variable (X1) which was measured through the Teh Pucuk Harum product instrument was a product that was hygienic and passed the test (KTP8) which was 0.742.

m. Product Quality Variable (X1) which was measured through the instrument of Teh Pucuk Harum products had the right sweet taste (KTP5) which was 0.719

n. Product Quality Variable (X1) which is measured through the instrument. The Teh Pucuk Harum product can improve mood (KTP1) has the lowest role, which is 0.688 .

2. Advertising variable $\left(\mathrm{X}_{2}\right)$

a. Advertising variable (X2) which is measured through the instrument of attractiveness of advertising stars on television affects consumers to buy Teh Pucuk Harum (IK5) which occupies the highest role in influencing the purchasing decision variable $(\mathrm{Y})$ which is 0.882 .

b. Advertising variable (X2) which is measured through the instrument of frequent advertisements in television media makes consumers easily influenced to buy Teh Pucuk Harum (IK6) products, which is 0.869 .

C. Advertising variable (X2) which is measured through the instrument. Consumers will be immediately attracted to the Teh Pucuk Harum product which is advertised on television media (IK10) which is 0.859 .

d. Advertising variable (X2) which is measured through advertising instrument using television media requires a large amount of funding (IK7) which is 0.842 .

e. Advertising variable (X2) which is measured through the instrument of messages conveyed by advertisements on television through visual images helps consumers to recognize and understand the characteristics of Teh Pucuk Harum (IK3) products, which is 0.814 .

f. Advertising variable (X2) which is measured through advertising instruments on television greatly influences consumers to purchase Teh Pucuk Harum (IK2) products, which is 0.801 .

g. Advertising variable (X2) which is measured through the instrument of attractiveness of advertising messages delivered through television makes consumers want to buy Teh Pucuk Harum products (IK4), which is 0.791 .

h. Advertising variable (X2) which is measured through advertising instruments on television can remind consumers regarding Teh Pucuk Harum products (IK1), which is 0.759 .

i. Advertising variable (X2) which is measured through a large advertising funding instrument is able to build a brand image of Teh Pucuk Harum (IK8) products, which is 0.691 .

j. Advertising variable (X2) which is measured through the instrument of advertising in television media can invite consumers to make purchases of Teh Pucuk Harum (IK9) products, which is 0.667 .

3. Brand Image Variable $\left(\mathrm{X}_{3}\right)$

a. The brand image variable (X3) which is measured through the Pucuk Harum Tea Product instrument is easily recognized from the logo and packaging (CM2) which occupies the highest role in influencing the purchasing decision variable (Y) which is 0.901 . 
b. The brand image variable $(X 3)$ which is measured through the product instrument of Teh Pucuk Harum has a good reputation so that consumers do not hesitate to buy it (CM3), which is 0.884 .

c. Brand image variable (X3) which is measured through a good reputation instrument for Teh Pucuk Harum products influences consumer purchasing decisions (CM4), which is 0.874 .

d. The brand image variable $(\mathrm{X} 3)$ which is measured through the product instrument for Teh Pucuk Harum is easily recognizable from the logo and packaging (CM1), which is 0.838 .

e. The brand image variable (X3) which is measured through the product instrument of Teh Pucuk Harum is easy for consumers to remember because of its slogan or tagline (CM5), which is 0.802

f. The brand image variable (X3) which is measured through the Teh Pucuk Harum brand instrument is easy to remember with the "pucuk-pucuk shoot" image (CM6) which is 0.744 .

\section{Inner Model Evaluation}

Testing of the Structural or inner model can be measured by looking at the Rsquare value which is the goodness-fit test of the model can be seen in table 3

Table 3 R-Square

\begin{tabular}{|l|c|}
\hline & R Square \\
\hline Product Quality $\left(\mathrm{X}_{1}\right)$ & 0.809 \\
\hline Advertising $\left(\mathrm{X}_{2}\right)$ & 0.414 \\
\hline Brand Image & 0.388 \\
\hline Purchasing Decision $(\mathrm{Y})$ & 0.157 \\
\hline
\end{tabular}

Source: Primary Data Processing Results, 2021

According to the Table 3 above, it can be explained that:

a. Nilai R-Square Kualitas Produk $\left(\mathrm{X}_{1}\right)$ terhadap Keputusan Pembelian ( $\mathrm{Y}$ ) 0,414, dimana dapat diinterprestasikan bahwa variabilitas Kualitas Produk berpengaruh positif lemah.

b. Nilai R-Square Iklan $\left(\mathrm{X}_{2}\right)$ terhadap Keputusan Pembelian $(\mathrm{Y})$ 0,388, dimana dapat diinterprestasikan bahwa variabilitas Iklan berpengaruh positif lemah.

c. Nilai R-Square Citra Merek $\left(\mathrm{X}_{3}\right)$ terhadap Keputusan Pembelian ( $\mathrm{Y}$ ) 0,157, dimana dapat diinterprestasikan bahwa variabilitas Citra Merekberpengaruh Negatif.

d. Nilai R-Square Kualitas Produk $\left(X_{1}\right)$, Iklan $\left(X_{2}\right)$, dan Citra Merek $\left(X_{3}\right)$ terhadap Keputusan Pembelian (Y) 0,809, dimana dapat diinterprestasikan bahwa variabilitas Kualitas Produk $\left(X_{1}\right)$, Iklan $\left(X_{2}\right)$, dan Citra Merek $\left(X_{3}\right)$ berpengaruh positif kuat.

\section{Hypothesis Test (Bootstrapping)}

Speculation testing is completed depending on the consequences of testing the Internal Model (underlying model) incorporating r-squared results, boundary coefficients, and t-insights. To see whether a theory can be acknowledged or rejected, among others, by focusing on the importance of esteem between build, t-insights, and p-values. Testing can be seen from the consequences of bootstrap. The basic guideline used in this review is t-measurements $>1.96$ with an importance level of $p$-values of $0.05(5 \%)$. The benefits of testing the theory of this review can be shown in the table. 
The Management Journal of BINANIAGA Vol. 06, No.02, December 2021

p-ISSN: 2527 - 4317, e-ISSN: $2580-149 x$

$6^{\text {th }}$ Accreditation Rating: April 04, 2019 - April 03, 2024

Table 4 Mean, STDEV, T-Values, P-Values

\begin{tabular}{|l|l|l|l|l|l|}
\hline & $\begin{array}{l}\text { Original } \\
\text { Sample } \\
(\mathrm{O})\end{array}$ & $\begin{array}{l}\text { Mean } \\
\text { Sample } \\
(\mathrm{M})\end{array}$ & $\begin{array}{l}\text { Standard } \\
\text { Deviation } \\
\text { (STDEV) }\end{array}$ & $\begin{array}{l}\text { T } \\
\text { Statistics } \\
(\mid \mathrm{O} / \mathrm{STD} \\
\mathrm{EV} \mid)\end{array}$ & P Values \\
\hline $\begin{array}{l}\text { Product Quality }\left(\mathrm{X}_{1}\right) \\
->\text { Purchasing } \\
\text { Decision }(\mathrm{Y})\end{array}$ & 0.414 & 0.414 & 0.136 & 3.053 & 0.002 \\
\hline $\begin{array}{l}\text { Advertising }\left(\mathrm{X}_{2}\right)-> \\
\text { Purchasing Decision }\end{array}$ & 0.388 & 0.432 & 0.191 & 2.031 & 0.043 \\
\hline $\begin{array}{l}\text { Brand Image }\left(\mathrm{X}_{3}\right)-> \\
\text { Purchasing Decision }\end{array}$ & 0.157 & 0.102 & 0.170 & 0.927 & 0.354 \\
\hline
\end{tabular}

Source: Primary Data Processing Results, 2021

According to the table 4 it can be explained that:

1. First Hypothesis Test

The value of $t$ statistic is 3.053 which is greater than $t$ table 1.96 with an error rate below 0.05 , which means that the first hypothesis $(\mathrm{H} 1)$ which states product quality (X1) on purchasing decisions $(Y)$ is acceptable.

2. Second Hypothesis Test

The t-statistic value of 2.031 is greater than t-table 1.96 with an error rate below 0.05 , which means that the first hypothesis $(\mathrm{H} 2)$ which states that advertising $(\mathrm{X} 2)$ on purchasing decisions $(\mathrm{Y})$ is acceptable.

\section{Third Hypothesis Test}

The value of $t$ statistic is 0.927 smaller than $t$ table 1.96 with an error rate below 0.05 , which means that the third hypothesis $(\mathrm{H} 3)$ which states the brand image $(\mathrm{X} 3)$ on purchasing decisions $(\mathrm{Y})$ is rejected.

The results of the analysis of the role of The Pucuk Harum product quality on Purchasing Decision.

1. The parameter coefficient (original sample) shows that the product quality construct (X1) has an effect on the Purchasing Decision construct $(Y)$ of $(0.414)$, this is because there are other variables that influence consumer purchasing decisions, where consumers are more considerate of the price of Teh Pucuk products. Affordable fragrance.

a. The instrument that has the most role in the Product Quality variable (X1) is the instrument for displaying the packaging design of the Teh Pucuk Harum product that looks good and attracts attention (KTP11) which occupies the highest role in influencing the Purchasing Decision variable $(\mathrm{Y})$ which is 0.859 .

b. The first hypothesis states that the t-statistic value of 3.053 is greater than ttable 1.96-96 (t-table $5 \%$ significance $=1.96$ ) which means that the first hypothesis of product quality $(\mathrm{X} 1)$ on purchasing decisions $(\mathrm{Y})$ is acceptable.

c. The theory put forward by (Fandy Tjiptono: 2006). Product quality is a state associated with products, services, which exceed expectations. The consumer's experience in using the product will result in the consumer's judgment of a product. If the The Pucuk Harum products will satisfy consumers, the consumers will give a positive assessment of the Te products. From the results of the descriptive analysis in table 4.2 , it shows that the quality of the product (X1) has an average of 4094 which means agree (interval value 3.41-4.20 = Agree). The highest value is found in the KTP14 indicator of 4.227, namely the statement "Teh Pucuk Harum Products have a good brand image reputation in consumers".

d. The results of this research are in line with research conducted by Baruna Hadi

Surya Bintarti; Suwandy. Consumer Purchasing Decisions of Teh Pucuk Harum : Product Quality, Advertising and Brand Image 
Brata 2017 in an article entitled "The Influence of Quality Products, Price, Promotian, and Location to Product Purchasing Decision on Nitchi at PT. Jaya Swarasa Agung in Central Jakarta" shows that product quality has a significant positive effect on purchasing decisions. And in another study conducted by Dewi Muliasari 2019 in an article entitled "The Effect of Product Price, And Product Quality on Purchasing Decisions for Samsung Mobile phones" showed that product quality has a positive effect on purchasing decisions.

2. The results of the analysis of the role of the Teh Pucuk Harum Advertisement on the Purchasing Decision.

a. The parameter coefficient (original sample) shows that the advertising construct $(\mathrm{X} 2)$ has an effect on the purchasing decision construct $(\mathrm{Y})$ of $(0.388)$, this is because the Teh Pucuk Harum product is already well known and attached to consumers.

b. The instrument that has the most role in the advertising variable (X2) is the instrument of attraction of advertising stars on television influencing consumers to buy Teh Pucuk Harum (IK5) which occupies the highest role in influencing the purchasing decision variable $(\mathrm{Y})$ which is 0.882 .

c. The second hypothesis states that the t-statistic value of 2.031 is greater than ttable 1.96 (t-table $5 \%$ significance = 1.96), which means that the second hypothesis of advertising ( $\mathrm{X} 2)$ on purchasing decisions $(\mathrm{Y})$ is acceptable.

d. The theory put forward by (Kotler \& Keller, 2010:132). Advertising is any form of non-personal presentation and promotion of ideas, goods or services by a particular sponsor for a fee. From the results of the descriptive analysis in table 4.3 , it shows that advertisements (X2) have an average of 4,185 which means agree (interval value 3.41-4.20 = Agree). The highest value is found in the IK 7 indicator of 4,333, namely the statement "Advertising using television media requires large funding.

e. The results of this study are not in line with the research conducted by Dan in subsequent research in line with Nor Aina's research in 2017. Researching "The Influence of Advertising and Brand Image on Purchasing Decisions for Honda Beat Motorcycles in Mugirejo Village, Sungai Samarinda District" shows that advertising has a positive effect on decisions. purchase. And in another study conducted by Nurmayanti and Pristiyono (2016), in an article entitled "The Effect of Advertising Attractiveness, Consumer Motivation and Product Quality on Purchasing Decisions for Mitsubishi Pajero Sport", shows that there is a positive influence of advertising attractiveness on purchasing decisions.

3. The results of the analysis of the role of the Teh Pucuk Harum Brand Image on Purchasing Decisions.

a. The parameter coefficient (original sample) shows the brand image construct $(X 3)$ to the Purchasing Decision construct $(Y)$ of $(0.157)$, this is because the brand image is not an additional reference to consumers and is a consideration for the products that consumers want.

b. The instrument that has the most role in the Brand Image variable (X3) is the product instrument for Teh Pucuk Harum which is easily recognizable from the logo and packaging (CM) which occupies the highest role in influencing the Purchasing Decision variable $(\mathrm{Y})$ which is 0.901 .

c. The third hypothesis states that the value of $t$ statistic $(0.927)$ is smaller than $t$ table 1.96 ( $t$ table significance $5 \%=1.96$ ) which means that the third hypothesis of brand image (X3) on purchasing decisions $(\mathrm{Y})$ is rejected.

d. The hypothesis put forward by Kotler and Keller (2009), brand image is a cycle in which an individual selects, combines, and describes the contribution of data to

Surya Bintarti; Suwandy. Consumer Purchasing Decisions of Teh Pucuk Harum : Product Quality, Advertising and Brand Image 
create a significant image. In addition, for buyers, a good brand image does not necessarily make them need to buy or try the item. Some buyers consider other things, such as the quality of the goods, the advice of companions or according to their own wishes. From the results of the different tests in table 4.4, it shows that the Brand Image (X3) has a normal of 4.223 which implies strongly agree (Worth span 4.20-5.00 = Emphatically Concur). The highest value was found on the pointer CM4 4,280, more precisely the statement "A good position for Teh Pucuk Harum products influences the Purchasing Decision of buyers". very persuasive." Judging from the results obtained, the brand image of Teh Pucuk Harum does not have a positive effect on purchasing choices. The results of this study are in line with research conducted by Siti Nurhayati in 2017 which examined "The Effect of Brand Image, Price and Promotion on Purchasing Decisions for Samsung Mobile Phones in Yogyakarta". Shows that Brand Image has no effect on Purchasing Decision. The results of this study explain that the image does not become an additional reference for potential consumers and becomes a consideration for the desired product. Brands that are widely known to the public and can be said to have a good brand image, so that people no longer consider it in deciding purchases. For consumers, a good brand image may not necessarily make them want to buy or try the product. Some consumers consider other things, such as the quality of products recommended by friends or according to their own wishes.

\section{CONCLUSION}

This review is directed to determine the impact of product quality, publication, and brand image on the buyer's choice to buy Teh Pucuk Harum. With the results obtained depending on research through survey dissemination and the completed SmartPLS information handling program, the results are as follows:

1. The quality of ready-to-drink tea products packaged with the Teh Pucuk Harum brand has a weak positive influence $(41 \%)$ on consumer purchasing decisions, where the instrument that has the role with the highest rating is the statement that the packaging design of the Teh Pucuk Harum product looks good and attracts attention. (KTP11). The weak role of Product Quality (X1) on Purchasing Decisions (Y) is because consumers are more concerned about the affordable price of Teh Pucuk Harum products.

2. Advertisements for ready-to-drink tea products packaged with Teh Pucuk Harum have a weak positive effect $(38 \%)$ on consumers' purchasing decisions, where the instrument that has the role with the highest rating is the statement that the attractiveness of television advertising stars influences consumers to buy fragrant shoots tea (IK5). The weak role of advertising (X2) on purchasing decisions ( $\mathrm{Y}$ ) is because the fragrant shoot tea product is already well-known and attached to consumers.

3. Brand image of ready-to-drink tea products packaged with Teh Pucuk Harum on consumer purchasing decisions $(15 \%)$ does not have a positive effect, where the instrument that has the role with the highest rating is the statement of the Teh Pucuk Harum product. It is easy to recognize from the logo and packaging (CM2). The weak role of Brand Image (X3) on Purchasing Decisions $(\mathrm{Y})$ is because brand image does not become an additional reference for consumers and becomes a consideration for the products that consumers want.

\section{REFERENCES}

Aditya \& Wardana. (2017). Peran Brand Equity dalam Memediasi Pengaruh Word Of Mouth terhadap Niat Beli. E-Jurnal Manajeman Unud. Vol. 6, No.2, 2017, Hal 830856, ISSN: 2302-8912. https://ojs.unud.ac.id 
Aghekyan-Simonian, M., Forsythe, S., Suk Kwon, W., \&Chattaraman, V. (2012). The role of product brand image and online store image on perceived risks and online purchase intentions for apparel. Journal of Retailing and Consumer Services, 19(3),

325-331.

https://doi.org/10.1016/j.jretconser.2012.03.006.

Anwar, A., \&Gulzar, A. (2011). Impact of brand image, trust and affect onconsumer brand extension attitude: The mediating role of brand loyalty. International Journal of Economics and Management Sciences, 1(5), 73-79. https://doi.org/10.1016/j.toxlet.2008.02.013.

Dina Agustina, (2015). Orang Indonesia Minum 2 Miliar Liter Teh Kemasan Setahun.https://m.cnnindonesia.com/gaya-hidup/20151103151544-26289179/orang- indonesia-minum-2-miliar--kemasan-setahun. (di akses pada 7 agustus 2021)

Eka Chusniartiningsi. (2019). pengaruh kesadaran merek, dan citra merek terhadap loyalitas pelanggan dengan kepercayaan merek sebagai variabel intervensing universitas- negri- surabya-jurnal ilmu manajeman. Vol 7, No. 1, 2019. ISSN:2549192X. https://journal.uin-alauddin.ac.id

Erik Moding Sara Rosengren. (2014). Can advertising creativity affect product perceptions and retailer evaluations, Journal of Product \& Brand Managemant (c) Emerald Publishing Limited, Vol. 23 Iss 6 PP. 452 - 461 http://dx.doi.org/10.1108/JPBM-2014-

0651https://www.ejournal.pelitaindonesia.ac.id/ojs32/index.php/PROCURATIO/articl e/view/44 4

Freddy Pendapotan. (2020). The Influence of Product Quality, Price Fairness,Brand Image, and Customer Value on Purchase Decision of Toyota Agya. Consumers: A Study of Low Cost Green Car. Terbit dijurnal binus.ac.id Vol.11No. 3 Hal. 187-196, ISSN:2476-9053.https//doi.10.21512/BBR.V11i3.6420.

Freddy Pandapotan Simbolon, ( 2020).The Influence of Product Quality, Price Fairness, Brand Image, and Customer Value on Purchase Decision of Toyota Agya Consumers: A Study of Low Cost Green Car. Terbit dijurnal binus.ac.id Vol.11 No. 3 Hal. 187-196, ISSN:2476-9053.https//doi.10.21512/BBR.V11i3.6420.

Hasby irwanto \& Husein, (2018). The Influence of Product Quality, Price Fairness, Brand Image, and Customer Value on Purchase Decision of Toyota Agya Consumers: A Study of Low Cost Green Car. Terbit dijurnal binus.ac.id Vol.11 No. 3 Hal. 187196, ISSN:2476-9053.https//doi.10.21512/BBR.V1113.6420.

He, M., Sha, Z., \& Yang, Y. (2013). An Empirical Study on Impacts of Brandlmage of Travel Agencies on Customer Purchase Intentions, (1992), 376-380. 380 https://atlantis-press.com

Hj. SuryaBintarti., (2015), Metodologi Penelitian Ekonomi Manajemen, Jakarta:Mitra Wacana Media.

Hj. Surya Bintarti, (2015) dalam buku Metodologi Penelitian EkonomiManajeman. Edisi 1. Jakarta:Mitra Wc https://www.tehpucukharum.com/pucuk-\%20defense (di akses pada 7 agustus2021)

Surya Bintarti; Suwandy. Consumer Purchasing Decisions of Teh Pucuk Harum : Product Quality, Advertising and Brand Image 
The Management Journal of BINANIAGA Vol. 06, No.02, December 2021

p-ISSN: $2527-4317$, e-ISSN: $2580-149 x$

$6^{\text {th }}$ Accreditation Rating: April 04, $2019-$ April 03, 2024

Imam Ghozali \& latan, (2015). Pengaruh Kualitas Pelayanan, Kualitas Produk Terhadap Loyalitas Nasabah dengan Kepuaan Nasabah Sebagi Variabel. Intervening, jurnal manajeman dan bisnis Vol 1, no. 2. Hal 87-110, ISSN:2686-0554 DOI: https//doi.org/10.47080/vol1no2/jumanis.

Indiarto. ( 2006). Pengaruh iklan terhadap keputusan pembelian apartemen meikarta. Jurnal Humaria Vol. 18, No. 1, Hal 59-66 ISSN:2579-3314 https://ejournal.bsi.ac.id

I Wayan Dicky, R., P., \& KM. Agus Satria. E-Jurnal Manajemen Unud, Vol. 7, No. 10, 2018:5230-5257ISSN:2302-8912 https://doi.org/10.24843/EJMUNUD.2018.v7.i10.p2

Josephp. Cannon (2008), THE EFFECT OF PRODUCT QUALITY, BRAND IMAGE AND ADVERTISING ON HONDA BEAT PURCHASING DECISIONS, Jurnal IImu dan

Pendidikan Ekonomi-Sosial" Volume 4, No. 1. Mei 2020 ISSN (2597-7806) ISSN (2597-7814) https://194.59.165.171

Justin Beneka. (2013).The influence of perceived product quality, relative price and risk on customer value and willingnesso buy: a study of private label merchandise. Journal of Product \& Brand Management, (c) Emerald Publishing Limited, Vol. 22 Issue: 3, pp.218-228. https://doi.org/10.1108/JPBM-02-2013-0262.

Latan, I, G (2020). Partial Least Square konsep, teknik dan aplikasi menggunakan program SmartPls 3.0. Edisi 1. Semarang: Badan Penerbit Undip.

Mohammed Z. Salem, (2017)1. " The effect of female portrayal inadvertising on the Palestinianfemales purchase decision". Terbit di journal of Islamic Marketing ( Emerald Publishing Limited, Vol. 11 N0. 2, pp. 282-300. https://doi.10.1108/JIMA$\underline{\text { 09-2017-0099 }}$

Mutsikiwa \& Marumbwa. (2013). Effects of perfume packaging on Basque female consumers purchase decision in Spain. Management Decision Vol. 56 No.8, 2018 pp. 1748-1768 @ Emerald Publishing Limited 0025-1747 DOI :10.1108/MD-042017-0363. https://doi.org/10.1108/MD-04-2017-0363

Nindya Kartika, K., N., \& Mochamad Reza, A., (2020). THE EFFECT OF PRODUCT QUALITY, BRAND IMAGE AND ADVERTISING ON

HONDA BEAT PURCHASING DECISIONS, Jurnal IImu dan Pendidikan Ekonomi-Sosial" Volume 4, No. 1. Mei 2020 ISSN 2597-7806, ISSN 2597-7814. https://194.59.165.171

Nor Aina. (2017). Pengaruh Iklan dan Citra Merek Terhadap Keputusan Pembelian Sepeda Motor Honda Beat Di Keluruhan Mugirejo Kecamatan Sungai Samarinda" Terbit di Journal Administrasi Bisnis Vol.3 No. 1. Hal. 180-192 ISSN:2355-5408 https//dx.doi.org/10.23887/jjpe.v11i2.21522. "Pertumuhan Belanja Iklan 2016 Kembali Normal" https:/www.nielsen.com/id/en/press-room/2017/pertumbuhanbelanja- iklan-2016 (di akses pada 7 agustus 2021)

Ghozali, Imam Ghozali, M.Com. (2014). pengaruh harga, citra merek dan kualitas pelayanan terhadap keputusan pembelian produk online jakmall, jurnal ilmiah manajeman bisnis, vol 6, no. 1, maret 202. https://publikasi.mercubuana.ac.id. 
Sugiyono. (2016:137). Pengaruh Motivasi dan Gaya Kepemimpinan Terhadap Produktivitas Kerja Pada Karyawan Bagian Produksi di PT TUNTEX GARMENT INDONESIA" Journal of Industrial Engineering \& ManagementVol. 1 No. 1 June 2020 : 70 - 82 e - ISSN 2272 - 8878 https://doi.org/10.7777/jiemar.v1i1.28

Sugiyono. (2016). Metode Penelitian Kuantitatif Kualititatif dan R\&D. Bandung : Alfabeta.

Sugiyono. (2017). Pengaruh Kualitas Pelayanan dan Harga Terhadap Kepuasan Pelanggan. Jurnal Riset Manajemen dan Bisnis (JRMB) Fakultas Ekonomi UNIAT Vol.4, No.1 Februari 2019: 37 - 44 P-ISSN 2527-7502 E-ISSN 2581-2165: DOI: https://doi.org/10.36226/jrmb.v4i1.240.

Sumardjono,S.\& Ardila, H.(2018). The Effect of Marketing Mix upon The Consumer's Decision Making to Buy a Product at PT. Griya Pagelaran Bogor. The Management Journal of Binaniaga, 3(1), 59-70. doi:10.33062/mjb.v3i1.241

Suri Amilia. (2017). Pengaruh Citra Merek, Harga, dan Kualitas Produk terhadap Keputusan Pembelian Handphone Merek Xiaomi di Kota Langsa. Jurnal MANAJEMEN DAN KEUANGAN, VOL.6, NO.1, Hal-660-669 ISSN 2252-844X.

Tjiptono (2012), "Pengaruh Kualitas Pelayanan dan Kualitas Produk Terhadap Kepuasan Konsumen Handphone Samsung". Jurnal IImiah Manajeman dan Bisnis Vol. 16, No. 2, Oktober 2015 ISSN : 1693-7619. DOI: https://dx.doi.org/10.30596\%2Fiimb.v16i2958

Tjiptono. (2008). Pengaruh iklan dan citra merek terhadap keputuan pembelian sepeda motor honda beat di samarinda jurnal administrasi bisnis. Vol. 5, No. 1, Hal: 180192, ISSN;2355-5408 https://ejournal.undiksha.ac.ai

Tjiptono. Pengaruh iklan dan citra merek terhadap keputusan pembelian produk sepeda motor merek honda pada dealer pt. Martha buana motor di singaraja. Jurnal pendidikan ekonomi Vol. 11 No. 2 ISSN-2599-1418. https://ejournal.undiksha.ac.ai

Tjiptono. (2008). The Effect of Brand Awareness, Prices, and Advertisement on Purchasedecision of Pucuk Harum Tea at Pelita Indonesia Pekan Baru.. Jurnal ilmiah manajeman Vol 7. No. 2, Juni 2019 (238-249) ISSN 2580-3743. ).

Wijaya \& Giantari. (2018). Analisis Elemen Brand Equity Pada Produk Minuman Teh Siap saji yang dikemas di Kota Denpasar. E-Jurnal Manajemen Unud, Vol. 7, No. 3, 2018: hal.1339-1367,ISSN:2302-8912. https://doi.org/10.24843/EJMUNUD.2018.v7.i03.p08

Wiwik Widiyanti. (2017). Pengaruh Persepsi Kualitas Produk, Citra Merek dan Media Iklan Instagram terhadap Keputusan Pembelian Produk Ninebox (Studi Kasus pada follower @tempattasdotcom). Terbit di Jurnal Humanioravol.17 No.1 ISSN: 1411-8629, e-ISSN:2579-3314.DOI:https/doi.org/10.31294/jc.v17i1.

Surya Bintarti; Suwandy. Consumer Purchasing Decisions of Teh Pucuk Harum : Product Quality, Advertising and Brand Image 
The Management Journal of BINANIAGA Vol. 06, No.02, December 2021

p-ISSN: 2527 - 4317, e-ISSN: $2580-149 x$

$6^{\text {th }}$ Accreditation Rating: April 04, $2019-$ April 03, 2024

This Page intentionally be emptied 